\title{
Roots and Tubers: An Alternate Energy Rich Feed Ingredients for Rural Pig Production
}

Netra Prasad Osti and Pulkit Mandal

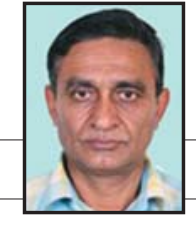

Netra Prasad Osti

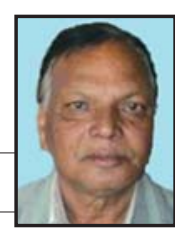

Pulkit Mandal

\begin{abstract}
Pigs are neglected domestic animal species reared under poor care and management. Chwanche, Hurra and Bampudke are major native pigs of Nepal whereas Landrace, Yarkshire, Pakhribash Black, Tamworth and Durock are the introduced pigs. A survey was conducted in selected districts of Nepal in order to understand feeding system of indigenous pigs and also collect feed samples for chemical analysis. In all surveyed sites, the pig herd size was relatively small (2-4/farm). Kitchen waste from home or hotel, local seasonal vegetable or fruit i.e. non-consumable for human being, local sweet potato and their vines (in few areas), roots and tubers and their leaves such as- Pindalu (Clocasea sps), Sweet potato (Ipomoea batatus L), Turnip (Brassia rape) and Radish (Raphnes sativa L), rice bran and maize flour were the major feed ingredients. Sweet potato had high energy content as compared to other roots and tubers and was comparable to rice bran and maize which are the major sources of energy in livestock feeds. Findings thus indicated that roots and tubers in rural areas could be an alternative as of energy rich feed ingredients which could be utilized if maize and rice bran are expensive and unavailable. Further research on level of feeding, conservation technique and varietals improvement is needed.
\end{abstract}

Kew words: Pig, roots, tubers, feed ingredients

\section{Introduction}

Traditionally pigs are most neglected domestic 1 animals. Local pigs have been raised by marginalized communities and so called upper cast people hesitate to eat pork but wild pigs (boars) are accepted everywhere and by all casts. Although, there is no religious barrier on pork, pigs are sacrificed in temples, social culture and caste specificity differed in pork consumption. In commercial pig production, 70 percent of total cost of production is from feeds, remaining cost goes for labor, medication, management etc. There are 11 millions pigs population and contribute 7 percent of total meat (250215 $\mathrm{mt} /$ year) supply in the country (MOAC 2009/10). Human excreta, kitchen waste, wastage from hotels, local vegetation, some plant fruits, roots and tubers are the major source of food for pigs. In addition to these feed ingredients, rice bran is the main source of bulk to mix with these local ingredients in rural areas. Chwanche, Hurra, Bampudke etc are the local pig breeds in Nepal. Improved pig breeds like Landrace, Yorkshire, Tamworth and Durock have been introduced in Nepal by various projects and Pakhribash black pig was developed in Nepal by three way crossing of Saddle block, Tamworth and Fayen breeds. In acceptation to Pakhribas black pig, developed in Nepal and popular in eastern hills by caste specificity (Rai and Limbu), other improved pigs and their crosses are localized in urban and semi-urban areas, in rural areas still local ecotype has been popular. Chwanche is popular in hills and mountain where as Hurra and Bampudke are popular in Terai and inner valley. Due to increasing urbanization and change in food habits scope of pig production has been increasing. Visualizing these feeding problems and possibility of searching alternative energy sources, a research work was carried out in periphery of Kathamndu, Dhading, Lalitpur and Kavre districts to know the existing situation of pig feeds and feeding and possible interventions.

\section{Materials and methods}

A survey was conducted on Nala of Kavre district, Jitpurphedi and Thankot of Kathamdnu district, and roadside areas and Dhadingbesi of Dhading district to know the feedstuffs and feeding situation of pigs. Along with survey, feeds and feeding materials samples were randomly collected and brought to animal nutrition laboratory for chemical analysis. Samples were dried at $72^{\circ} \mathrm{C}$ over night in constant weight in hot air oven. Dried samples were grind and passed through $1 \mathrm{~mm}$ sieve and stored for chemical analysis. Samples were analyzed for dry matter (DM), crude protein (CP), ether extract (EE) and gross energy (GE) according to AOAC (1990). Similarly neutral detergent fiber (NDF), acid detergent fiber (ADF) and lignin were analyzed according to Van Soest et al (1985) in animal nutrition laboratory Khumaltar, Lalitpur, Nepal.

\section{Results and discussions}

Most of pigs raising system were found small in size (2-4/farm), use waste materials (hotel waste, mill byproducts, slaughter house waste; viscera and offal) for pig feeding. Seasonal vegetation like clocasea stems, reddish, turnips, local sweet potato vines etc which are excess from human consumption being fed to pig with waste materials. The mean DM, CP, EE, NDF, ADF and Lignin content of Karkalo, Pidalu, Sakharkhanda, Sakharkhand vines, Salgam, Seto Mula, Dhuto and Makai ko Pitho (maize flour) were found 97.66, 12.72, 1.71, 53.64, 32.24 and 12.36 percent respectively. The mean gross energy content was found $3178.04 \mathrm{Cal} / \mathrm{g}$, highest found in Makai Ko Pitho and lowest in Seto Mula (white radish) (table 1). Sweet potato content $3182 \mathrm{KCal} / \mathrm{Kg}$ Gross Energy (GE) which is comparable to maize, therefore sweet potato cultivation can replace maize for pig feeding. Most of roots and tubers crops are easy to cultivate. Require less tillage, irrigation and can cultivate in less fertile and marginal land. These crops intercrop with maize, easy to harvest and ultimately cost of production is very low compared with other food grain crops.

Native pigs are rear under scavenging feeding system and improved pigs are mainly raise by hotel owners and wild pigs (Sus salvanilis) are also raised by so called 


\begin{tabular}{|l|r|r|r|r|r|r|r|}
\hline \multicolumn{1}{|c|}{ Name of sample } & DM \%* & \multicolumn{1}{c|}{ CP \% } & \multicolumn{1}{c|}{ EE \% } & $\begin{array}{c}\text { Energy } \\
\text { (KCal/ kg) }\end{array}$ & \multicolumn{1}{c|}{ ADF \% } & NDF \% & Lignin \% \\
\hline Karkalo (Clocasia species) & 96.89 & 11.35 & 1.87 & 2839.91 & 43.03 & 50.72 & 17.65 \\
\hline Pidalu (Clocasia species) & 97.89 & 9.48 & 0.03 & 2899.68 & 23.59 & 53.64 & 9.76 \\
\hline Sakharkhand (Ipomoea batatus L.) & 98.30 & 4.97 & 0.01 & 3181.89 & 10.55 & 71.26 & 4.69 \\
\hline $\begin{array}{l}\text { Sakharkhand ko Lahara } \\
\text { (Ipomoea batatus L.) }\end{array}$ & 97.87 & 14.73 & 1.46 & 3139.04 & 48.72 & 55.12 & 19.07 \\
\hline Salgam (Brassica rape I.) & 97.61 & 16.76 & 1.36 & 2998.93 & 42.73 & 49.70 & 22.14 \\
\hline Seto Mula (Raphnus sativus L.) & 97.17 & 17.35 & 1.08 & 2808.65 & 44.11 & 49.93 & 20.17 \\
\hline Karkalo (Clocasia species) & 97.25 & 14.07 & 3.26 & 3149.11 & 35.95 & 42.48 & 9.94 \\
\hline Rice Bran (Oriza sativa) & 97.82 & 15.74 & 5.08 & 4126.13 & 10.99 & 51.51 & 3.39 \\
\hline Makai ko Pitho (Zea Maize) & 98.10 & 10.04 & 1.29 & 3458.98 & 30.45 & 58.39 & 4.40 \\
\hline Mean & 97.66 & 12.72 & 1.71 & 3178.04 & 32.24 & 53.64 & 12.36 \\
\hline
\end{tabular}

Table1. Nutritive value of locally available feedstuff used for pig feeding in Kathmandu periphery (DM basis)

* Dry matter percent given in this text are as air dry basis

upper cast people and get higher price compared to native and improved pig (pork). People living in high hills and mountain communities, specially marginalized communities migrated to semi-urban and road sides and river basin for better livelihood. These communities have tradition to raise pigs, some people owned hotel business and pigs as extra business. These marginalized people now raise pigs instead of owing hotel business. In urban areas, pork has been gaining popularity due to changing food habits of young people; they very much like pork as fast food. Very few commercial pig farms are seen in the country. Some ethnic background people raise commercial type farm but the pig farms are near to human settlements (building) and not with proper sanitation and waste disposal which leads to urban environmental pollution.

\section{Conclusion}

The price of pig raising is increasing day by day due to uses of grains as pig feed and also more grains needed for increasing human population. Hence roots and tubers could be beneficial for pig raising farmers by getting more meat at lower price. Feeding of pigs in rural areas is traditional type while in urban and semi-urban areas people use waste materials from hotel and restaurants. Laboratory analyses of this study show that sweet potato contains high level of energy comparable to maize which could be an alternative energy source for future pig production for landless and marginal farmers.

Pulkit Mandal, M.Sc (Animal Sceince), is Chief of Animal Nutrition Division of National Animal Science Research Institute (NASRI) under Nepal Agricultural
Research Council (NARC). Mr. Mandal was graduated from University of Philippines, Los Banos. He is currently working as senior Scientist (S4) in the area of animal nutrition and production. Mr. Mandal has published about 25 papers in national and international journal and proceedings.

Corresponding Address: annd@narc.gov.np

Netra Prasad Osti, M.Sc. Animal Science (Animal Nutrition), is Senior Scientist (S4) in the field of Animal Nutrition and Feeding. He graduated from Institute of Agriculture and Animal Science (IAAS) Rampur Chitwan under Tribhuvan University, Nepal. Currently, he is working in Animal Nutrition Division of NASRI under NARC, his duties include preparation of research projects; implement approved research projects, monitoring and evaluation of research projects. Mr. Osti has published 50 papers in national and international journals and proceedings.

Corresponding Address: ostinp@narc.gov.np; n_osti@ yahoo.com

\section{References}

AOAC. 1990. Official Method of Analysis. 15 $5^{\text {th }}$ edition. (Association of Official Analytical Chemist) Washington, DC. USA pp. 66-88.

Ministry of Agriculture and Cooperatives (MOAC) 2009/10. Statistical Information of Nepal http://www. moac.gov.np/content.php?id=234

Van Soest, P.J., J.D. Robertson and B.A. Lewis. 1991. Methods for dietary fiber, neutral detergent fiber and non-starch polysaccharides in relation to animal nutrition. Journal of Dairy Science. 74:3583-3597. 